\title{
PREDIKSI GENOTIPE TETUA JAGUNG BERBULIR UNGU BERDASARKAN KESESUAIAN NISBAH HARAPAN PADA BULIR $S_{1}$ DAN $\mathrm{S}_{2}$
}

\section{PARENT GENOTYPES PREDICTION OF PURPLE CORN BY SUITABILITY OF EXPECTED RATIO ON KERNEL $S_{1}$ AND $S_{2}$}

\author{
Yefta Pamandungan'), Aziz Purwantoro'2) dan Panjisakti Basunanda2) \\ 1) Jurusan Budidaya Pertanian Fakultas Pertanian Unsrat, Manado \\ 2) Program Studi Pemuliaan Tanaman Fakultas Pertanian UGM, Yogyakarta
}

\begin{abstract}
The research was aimed to determine the parent genotypes of purple corn by the similarity of expected ratio on kernels $S_{1}$ and $S_{2}$ using four locus models, $P r / p r, C / c, R / r$ and $Y / y$ genes. The study was conducted in two phases, namely, 1) Making the individuals of selfing to-1 ( $\left.\mathrm{S}_{1}\right)$, and 2) Making the individuals of selfing to-2 $\left(\mathrm{S}_{2}\right)$. Observed data in the form of kernel per ear of corn was separated by the characters of purple, yellow and white color then analyzed by using the Chi-square Test. The results showed that the offspring genotype from selfing on the base population can be predicted by looking at the suitability between the offspring and parental genotypes based on the ratio of expectation. Parent genotypes prediction on the base population of selfing were PrPrCcRrYy, PrPrCcRryy, PrPrCcRrYY, PrPrCcRRYY and PrPrCCRrYY.
\end{abstract}

Keywords: parent genotypes, purple kernel, corn

\begin{abstract}
ABSTRAK
Tujuan penelitian ini adalah mengetahui genotipe tetua jagung berbulir ungu berdasarkan kesesuaian dengan nisbah harapan pada bulir $\mathrm{S}_{1}$ dan $\mathrm{S}_{2}$ menggunakan model empat lokus yaitu gen $\mathrm{Pr} / \mathrm{pr}, \mathrm{C} / \mathrm{c}, \mathrm{R} / \mathrm{r}$ dan $Y / y$. Penelitian dilakukan dalam dua tahap yaitu, 1) pembuatan individu hasil selfing ke-1 $\left(\mathrm{S}_{1}\right)$, dan 2) pembuatan individu hasil selfing ke-2 $\left(S_{2}\right)$. Data hasil pengamatan berupa bulir jagung per tongkol yang dipisahkan berdasarkan karakter warna ungu, kuning dan putih selanjutnya dianalisis dengan menggunakan uji khi kuadrat. Hasil penelitian menunjukkan bahwa genotipe keturunan hasil selfing pada populasi dasar dapat diprediksi dengan melihat kesesuaian antara genotipe keturunan dan tetua

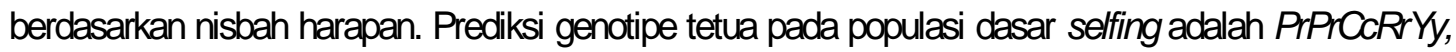
PrPrCcRryy, PrPrCcRrYY, PrPrCcRRYY dan PrPrCCRrYY.

Kata kunci: genotipe tetua, berbulir ungu, jagung
\end{abstract}

Eugenia Volume 18 No. 3 Desember 2012 


\section{PENDAHULUAN}

Jagung (Zea mays L.) merupakan salah satu serealia yang strategis dan bernilai ekonomis karena kedudukannya sebagai sumber utama karbohidrat dan protein setelah beras. Hampir seluruh bagian tanaman jagung dapat dimanfaatkan untuk berbagai macam keperluan yaitu pakan ternak, pupuk hijau atau kompos, kertas, bahan baku farmasi, perekat, tekstil, minyak goreng, etanol (Purwanto, 2008). Jagung juga merupakan tanaman penting dalam teknologi biopharming yaitu bercocok tanam tanaman transgenik yang menghasilkan bahan-bahan yang memiliki fungsi kesehatan (pharmaceutical products) seperti obat-obatan, antibodi dan protein (Elbehri, 2005).

Di Indonesia, perakitan kultivar baru jagung dengan melibatkan sifat warna bulir dapat dilakukan untuk mendukung sektor industri. Jagung berbulir ungu dapat dimanfaatkan sebagai bahan baku pembuatan makanan tambahan (supplement) yang berguna untuk kesehatan. Oleh karena itu, perakitan genetik yang dilakukan perlu didasari dengan pemahaman mengenai informasi kendali genetik (pewarisan) sifat warna bulir jagung sehingga menunjang keberhasilan program pemuliaan tanaman.

Tanaman jagung termasuk dalam kelompok tanaman berpenyerbukan silang. Dengan demikian, tingkat keragaman jagung menjadi tinggi, apalagi jika tersedia dalam populasi yang heterogen. Tingginya tingkat heterozigositas populasi maka komposisi genetik hasil persilanganpun menjadi sangat beragam.

Komposisi genetik populasi jagung hasil persilangan dapat diketahui dengan memanfaatkan informasi genetik dari gen-gen pengendali warna bulir untuk memprediksi komposisi harapan pada generasi hasil persilangannya. Pewarisan informasi genetik dapat dipelajari lewat Hukum Mendel yang menyatakan bahwa alel akan memisah (segregasi) satu dengan yang lainnya selama pembentukan gamet dan diwariskan secara rambang ke dalam gamet-gamet dengan jumlah yang sama (Crowder, 2006).

Warna ungu, merah dan kuning pada bulir jagung dihasilkan dengan adanya sintesis pigmen yaitu dari kelompok antosianin (pigmen ungu dan merah) atau karotenoid (pigmen kuning). Warna putih pada bulir dihasilkan karena ketiadaaan pigmen dari kelompok antosianin dan karotenoid (Ford, 2000).

Sintesis pigmen pada bulir jagung memerlukan peranan beberapa gen yaitu gen struktural (structural gene) yang berfungsi untuk mengkode enzim yang berperan dalam sintesis pigmen dan gen regulator (regulatory gene) yang berfungsi sebagai aktivator transkripsi dan mengkode protein yang mengontrol transkripsi dari gen struktural (Ford, 2000). Gen regulator dapat menghasilkan sebuah produk yang mengontrol transkripsi gen lainnya dan mengaktifkan sintesis pigmen antosianin oleh gen struktural (Klug et. al., 1997).

Kempton (1919) mengasumsikan bahwa ada tiga faktor yang mempengaruhi produksi warna pada aleuron bulir jagung. Faktor utama yaitu gen $C$ penting dalam menghasilkan warna bulir, faktor penentu warna merah yaitu gen $R$ dimana adanya interaksi dengan gen $C$ akan menghasilkan bulir warna merah dan faktor penentu warna ungu yaitu gen Pr. Warna ungu akan terlihat pada bulir jagung saat terdapat gen $C$ dan $R$.

Menurut Sharma et. al. (2011), genotipe warna ungu dan merah yang seharusnya ada pada bulir jagung adalah Pr/-, C1/-, R1/-, dan pr/pr, C1/-, R1/-. Bulir jagung tampak tak berwarna dengan adanya alel $c 1 / c 1$ atau $r 1 / r 1$. Adanya gen yang berperan dalam pembentukan warna bulir jagung juga telah dijelaskan oleh Ford (2000). Gen-gen tersebut adalah gen $\operatorname{Pr}, C, R$ dan $Y$ yang oleh ahli genetika jagung disebut sebagai color gene.

Untuk aleuron yang berwarna, alel $C$ dan $R$ harus hadir. Alel homozigot resesif (c/c atau $r / r$ ) mengganggu produksi antosianin dan menghasilkan aleuron yang tak berwarna. Alel $C^{\prime}$ (C1-I) menghambat produksi antosianin, sehingga menghasilkan aleuron yang tak berwarna. Gen $C$ dan $R$ terletak pada kromosom yang terpisah dan bersegregasi secara bebas. Alel $\operatorname{Pr}$ berinteraksi dengan alel $C$ dan $R$ untuk menghasilkan aleuron ungu. Kondisi homozigot resesif (pr/pr) berinteraksi dengan alel $C$ dan $R$ menghasilkan aleuron merah. Semua kombinasi faktor di luar interaksi dengan $C$ dan $R$ menyebabkan aleuron tidak berwarna 
sehingga warna bulir yang tampak berasal dari adanya gen $Y$ atau $y$ yaitu berwarna kuning atau putih (East, 1912). Perbedaan warna yang terlihat pada bulir jagung disebabkan karena adanya interaksi antara gen struktural (Pr/pr dan $Y / y)$ dengan gen regulator $(C / c$ dan $R / r)$.

Pada saat gen regulator aktif ( $C$ - dan $R$-), gen $\operatorname{Pr}$ mengkode enzim flavonoid 3'-hydroxylase yaitu enzim yang berperan dalam produksi sianidin glikosida (cyanidin-glicoside) atau pigmen ungu pada jalur sintesis antosianin (Donner et. al., 1991). Gen $\mathrm{pr} / \mathrm{pr}$ menyebabkan tidak adanya enzim flavonoid 3'-hydroxylase sehingga warna bulir menjadi merah karena diproduksinya pigmen merah atau pelargonidin glikosida (pelargonidin glycoside). Pada saat gen regulator tidak aktif, gen struktural lainnya yaitu gen $Y$ mengkode enzim phytoene synthetase yaitu sebuah enzim yang diperlukan pada jalur sintesis karotenoid sehingga menghasilkan warna kuning pada bulir jagung.

Dengan model empat lokus gen yang berperan dalam pembentukan warna pada bulir jagung maka penelitian ini dilaksanakan dengan tujuan untuk memprediksi genotipe tetua jagung berbulir ungu berdasarkan kesesuaian nisbah harapan pada bulir $S_{1}$ dan $S_{2}$.

\section{METODE PENELITIAN}

Penelitian ini dilaksanakan di Kebun Percobaan Fakultas Pertanian Universitas Gadjah Mada Yogyakarta dengan dua tahapan. Tahapan pertama penelitian yaitu pembuatan individu hasil selfing ke-1 $\left(\mathrm{S}_{1}\right)$ yang dilaksanakan dari bulan Oktober - Desember 2009. Tahapan kedua yaitu pembuatan individu hasil selfing ke-2 $\left(\mathrm{S}_{2}\right)$ yang dilaksanakan dari bulan Januari - April 2010.

Bahan yang digunakan dalam penelitian ini adalah bulir jagung (warna ungu, ukuran sedang) yang dibeli dari pasar tradisional Bantul, Yogyakarta dan belum diketahui tingkat kemurniannya. Peralatan yang digunakan adalah traktor, cangkul, garu, penugal, gembor, gunting, staples, kantong kertas minyak, kertas label, gunting, bolpoin, penggaris, jangka sorong dan kantong plastik.
Pengamatan dilakukan terhadap banyaknya bulir per tongkol dan dipisahkan berdasarkan kelas fenotipe warna bulir yaitu warna ungu, kuning dan putih yang dihitung secara manual.

\section{Prosedur Kerja \\ Penanaman Benih, Pemupukan dan Pemeliharaan Tanaman}

Pada tahapan penelitian yang pertama, penanaman dilakukan di lahan yang telah dipersiapkan dengan memasukkan 1 butir benih jagung ke dalam satu lubang yang telah dibuat dengan jarak tanam $90 \mathrm{~cm} \times 30 \mathrm{~cm}$ kemudian benih ditutup dengan tanah. Penanaman ini diatur berdasarkan ketersediaan benih sehingga populasi tanaman jagung yang didapati nantinya adalah populasi jagung berbulir ungu.

Setelah jagung tumbuh dan berumur 1 minggu, dilakukan pemupukan pertama dengan dosis pupuk NPK $100 \mathrm{~kg} / \mathrm{ha}$. Pemupukan kedua dilakukan saat tanaman berumur 4 minggu dengan memberikan pupuk urea $200 \mathrm{~kg} / \mathrm{ha}$. Pada saat pemupukan, pupuk ditebar secara merata dalam alur yang dibuat 7,5 - $10 \mathrm{~cm}$ dari baris tanaman dengan kedalaman $10 \mathrm{~cm}$ dan segera segera dilakukan pembumbunan sehingga pupuk akan tertutup. Pemeliharaan tanaman meliputi penyiraman sesuai dengan kebutuhan tanaman dan penyiangan gulma dilakukan apabila dibutuhkan.

\section{Persilangan Tanaman}

Tahapan awal persilangan adalah memperhatikan dengan seksama keberadaan bunga jantan dan betina. Sebelum mekar dan mengeluarkan rambut, bunga betina harus dikerodongi dengan menggunakan kertas kerodong untuk menghindari persilangan yang tidak dikehendaki. Sebelum mekar dan mengeluarkan serbuk sari, bunga jantan dikerodongi dengan menggunakan kantong kerodong. Pada 1 - 3 hari berikutnya serbuk sari akan tertampung dalam kantong dan dapat digunakan untuk menyerbuki sendiri (selfing).

Penyerbukan dilakukan pada pukul 08.00 12.00 WIB. Bunga betina yang diserbuki yaitu bunga yang telah mengeluarkan putik atau rambut. Sebelum diserbuki, kerodong dibuka dan tabung putik dipotong dengan pisau yang bersih. Serbuk 
sari dioleskan ke bagian putik yang telah dipotong setelah itu dikerodongi kembali, dijepit dan masingmasing persilangan diberi label.

Penyerbukan sendiri (selfing) ke-1 dilakukan pada populasi tetua jagung berbulir ungu (U), dimana serbuk sari pada tetua jagung tersebut digunakan untuk menyerbuki sendiri sehingga diperoleh bulir $S_{1}$. Setelah tanaman masak fisiologis $( \pm$ 115 hari setelah tanam) tongkol dari tanaman yang telah disilangkan dikeringkan secara alami kemudian dipipil dengan tangan. Bulir tersebut selanjutnya dimasukkan ke dalam kantong plastik dan diberi label sesuai dengan perlakuan persilangannya.

Pelaksanaan penelitian pada tahapan kedua sama dengan tahapan pertama dimana persiapan lahan, penanaman dan pemeliharaan tanaman dilakukan seperti pada penelitian tahap pertama. Hanya saja pada tahap kedua, persilangan dilakukan dengan cara serbuk sari dari masing-masing tetua $S_{1}$ digunakan untuk menyerbuki sendiri (selfing) sehingga diperoleh bulir $\mathrm{S}_{2}$.

\section{Analisis Data}

Data hasil penelitian dianalisis dengan menggunakan uji $x^{2}$ (khi kuadrat) dengan rumus sebagai berikut :

$X^{2}=\sum \frac{()^{2}}{}$, untuk

$\sum \quad=$ tanda jumlah

$\mathrm{d}=$ selisih antara hasil yang diperoleh dengan hasil yang diharapkan $(0-e)$

$0=$ observed atau hasil yang diperoleh/diamati

$\mathrm{e}=$ expected atau hasil yang diharapkan

Dengan melihat kesesuaian antara nisbah

hasil yang diamati dengan nisbah hasil yang diharapkan maka genotipe tetua dapat diprediksi.

\section{HASIL DAN PEMBAHASAN}

Sifat warna ungu pada bulir jagung terekspresi saat genotipe tetua tersusun atas gengen yang mengendalikan warna ungu. Susunan gen pengendali tersebut adalah PrCRY atau PrCRy sehingga diperoleh 24 genotipe yang mengekspresikan sifat warna ungu pada bulir jagung (Tabel 1). Berdasarkan simulasi hasil selfing dari 24 genotipe tersebut, diperoleh 14 kelompok nisbah harapan hasil selfing (Tabel 2).

Penyerbukan sendiri (selfing) dilakukan pada 6 (enam) tanaman jagung $\left(U_{1}, U_{2}, U_{3}, U_{4}, U_{5}\right.$ dan $U_{6}$ ) dalam populasi dasar tanaman jagung berbulir ungu, diperoleh bulir hasil selfing ke-1 atau bulir $S_{1}\left(S_{1} U_{1}, S_{1} U_{2}, S_{1} U_{3}, S_{1} U_{4}, S_{1} U_{5}\right.$ dan $\left.S_{1} U_{6}\right)$ kemudian diseleksi berdasarkan karakter warna ungu untuk digunakan sebagai benih dan ditumbuhkan menjadi tanaman $S_{1}$ jagung berbulir ungu. Penyerbukan sendiri pada tanaman $S_{1}$ jagung berbulir ungu $\left(S_{1} U_{1}, S_{1} U_{2}, S_{1} U_{3}, S_{1} U_{4}, S_{1} U_{5}\right.$ dan $S_{1} U_{6}$ ) menghasilkan bulir hasil selfing ke-2 atau bulir $\mathrm{S}_{2}\left(\mathrm{~S}_{2} \mathrm{U}_{1}, \mathrm{~S}_{2} \mathrm{U}_{2}, \mathrm{~S}_{2} \mathrm{U}_{3}, \mathrm{~S}_{2} \mathrm{U}_{4}, \mathrm{~S}_{2} \mathrm{U}_{5}\right.$ dan $\left.\mathrm{S}_{2} \mathrm{U}_{6}\right)$. Berawal dari selfing yang dilakukan pada populasi dasar $\left(U_{1}, U_{2}, U_{3}, U_{4}, U_{5}\right.$ dan $\left.U_{6}\right)$ maka selanjutnya dapat diprediksi nisbah harapan warna bulir $\mathrm{S}_{1}$ dan $\mathrm{S}_{2}$ serta genotipe tetuanya (Tabel 3).

\section{Tanaman $\mathrm{U}_{1}$}

Penyerbukan sendiri ke-1 $\left(S_{1}\right)$ tanaman $U_{1}$ menghasilkan bulir $S_{1}$ sebanyak 93:72:31 (ungu: kuning:putih) yang bila di uji khi kuadrat sesuai dengan nisbah harapan 36:21:7 (ungu:kuning: putih). Dengan demikian, dapat diprediksi bahwa genotipe tanaman $U_{1}$ adalah PrPrCcRrYy. Bulir ungu hasil $S_{1}$ tersebut digunakan sebagai benih dan ditumbuhkan menjadi tanaman $S_{1} U_{1}$. Penyerbukan sendiri ke-2 (selfing ke-2) pada beberapa nomor tanaman $S_{1} U_{1}$ menghasilkan bulir $S_{2}$ yang sesuai dengan nisbah harapan 3:1 (ungu:kuning), sesuai dengan nisbah harapan 12:3:1 (ungu:k uning:putih) dan 36:21:7 (ungu:kuning:putih). Prediksi genotipenya adalah PrPrCcRRYY atau PrPrCCRrYY untuk nisbah 3:1 (ungu:kuning), PrPrCcRRYy atau PrPrCCRrYy untuk nisbah 12:3:1 (ungu:kuning:putih), dan PrPrCcRrYy untuk nisbah harapan 36:21:7 dimana semuanya memiliki kesamaan genotipe dengan bulir ungu hasil selfing ke-1 pada tanaman $\mathrm{U}_{1}$.

\section{Tanaman $\mathrm{U}_{2}$}

Penyerbukan sendiri ke-1 $\left(S_{1}\right)$ tanaman $U_{2}$ menghasilkan bulir $S_{1}$ sebanyak 74:76 (ungu:putih) yang sesuai dengan nisbah harapan 9:7 (ungu:putih). Dapat diprediksi bahwa genotipe tanaman $\mathrm{U}_{2}$ adalah PrPrCcRryy. Bulir ungu hasil $\mathrm{S}_{1}$ 
digunakan sebagai benih dan ditumbuhkan menjadi tanaman $\mathrm{S}_{1} \mathrm{U}_{2}$. Penyerbukan sendiri ke-2 $\left(\mathrm{S}_{2}\right)$ pada 2 nomor tanaman $S_{1} U_{2}$ menghasilkan bulir $S_{2}$ yang sesuai dengan nisbah harapan yaitu $3: 1$ (ungu:putih), 9:7 (ungu:putih) sehingga prediksi genotipe dari masing-masing nisbah harapan tersebut adalah PrPrCcRRyy atau PrPrCCRryy dan PrPrCcRryy yang memiliki kesamaan genotipe dengan tanaman $\mathrm{U}_{2}$ atau bulir hasil $\mathrm{S}_{1} \operatorname{tanaman} \mathrm{U}_{2}$.

\section{Tanaman $\mathrm{U}_{3}$}

Penyerbukan sendiri ke-1 $\left(\mathrm{S}_{1}\right)$ tanaman $\mathrm{U}_{3}$ menghasilkan bulir $S_{1}$ sebanyak 12:13 (ungu:kuning) yang sesuai dengan nisbah harapan 9:7 (ungu:kuning). Dapat diprediksi bahwa genotipe tanaman $\mathrm{U}_{3}$ adalah PrPrCcRrYY. Bulir ungu hasil $\mathrm{S}_{1}$ digunakan sebagai benih dan ditumbuhkan menjadi tanaman $S_{1} U_{2}$. Penyerbukan sendiri ke-2 $\left(S_{2}\right)$ pada tanaman $S_{1} U_{3}$ menghasilkan bulir $S_{2}$ yang sesuai dengan nisbah harapan 9:7 (ungu:kuning) sehingga diprediksi bahwa genotipe tanaman $\mathrm{S}_{1} \mathrm{U}_{3}$ adalah $\operatorname{PrPrCcRrYY}$ (sama dengan genotipe tanaman $\mathrm{U}_{3}$ ).

\section{Tanaman $\mathrm{U}_{4}$}

Penyerbukan sendiri ke-1 $\left(\mathrm{S}_{1}\right)$ tanaman $\mathrm{U}_{4}$ menghasilkan bulir $S_{1}$ sebanyak 51:1:8 (ungu:kuning:putih) yang tidak sesuai dengan nisbah harapan 12:3:1 (ungu:kuning:putih) sehingga genotipe tanaman $\mathrm{U}_{4}$ tidak dapat diprediksi. Walaupun demikian, bulir ungu hasil $\mathrm{S}_{1}$ tanaman $U_{4}$ tetap digunakan sebagai benih untuk ditumbuhkan menjadi tanaman $S_{1} U_{4}$. Penyerbukan sendiri ke-2 $\left(\mathrm{S}_{2}\right)$ pada $\mathrm{S}_{1} \mathrm{U}_{4}$ menghasilkan bulir $\mathrm{S}_{2}$ yang sesuai dengan nisbah harapan nisbah $3: 1$ (ungu:kuning) sehingga dapat diprediksi bahwa genotipe tanaman $\mathrm{S}_{1} \mathrm{U}_{4}$ adalah $\operatorname{PrPrCcRRYY}$ atau PrPrCCRrYY.

Tabel 1. Gen Pengendali Sifat Warna Ungu Pada Bulir Jagung dan Genotipenya (Table 1. Genes Controlling of Corn Purple Kernels and the Genotype)

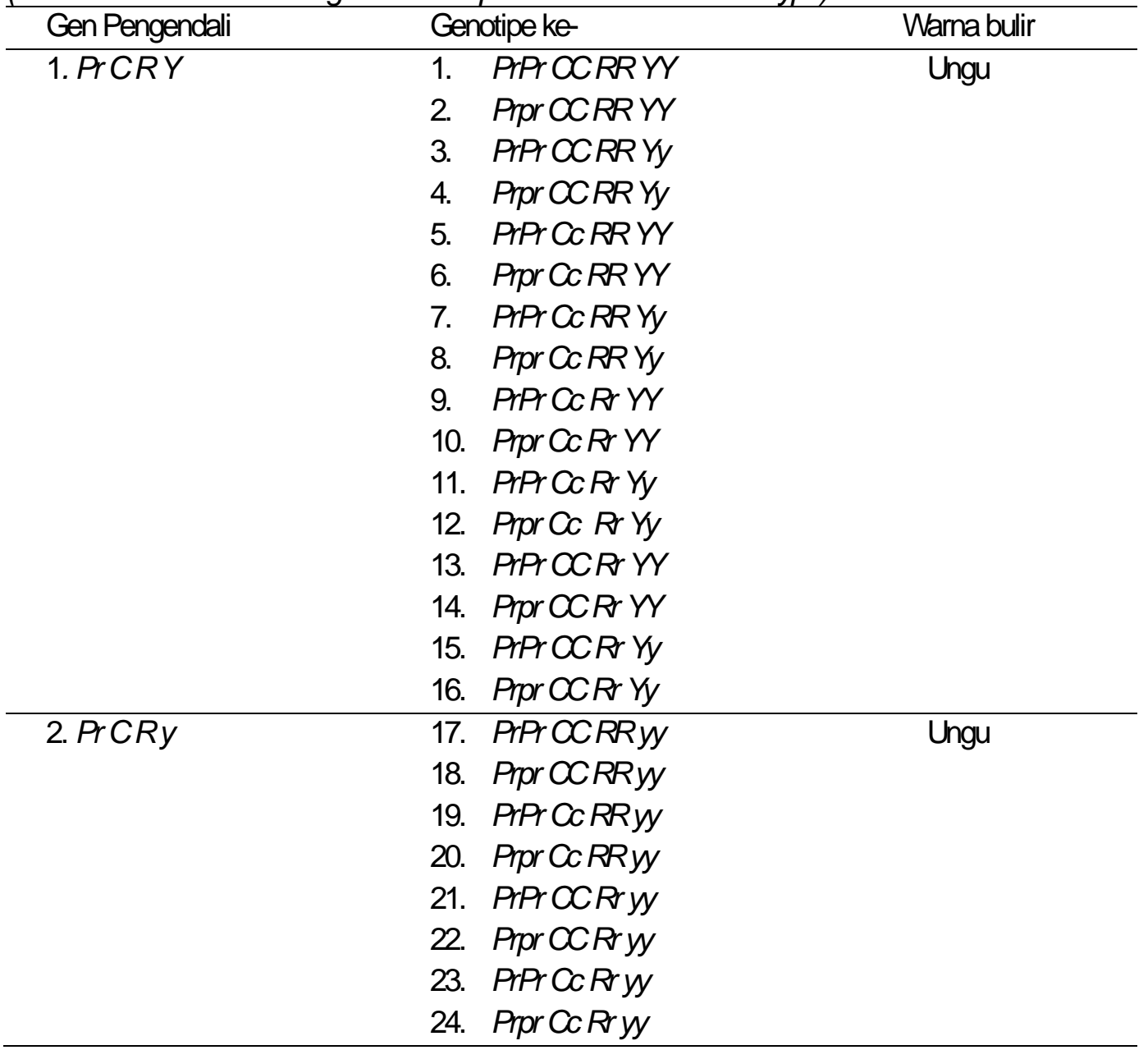


Tabel 2. Nisbah Harapan dari Hasil Penyerbukan Sendiri (selfing) 24 Genotipe Pengendali Sifat Warna Ungu pada Bulir Jagung.

(Table 2. Expected Ratio from Selfing 24 Genotypes of Purple Genes Controlling on Corn Kernels)

\begin{tabular}{|c|c|c|c|}
\hline No. & Nisbah harapan & Selfing genotipe ke- & $\begin{array}{l}\text { Genotipe bulir ungu } \\
\text { hasil selfing }\end{array}$ \\
\hline \multirow[t]{3}{*}{1.} & Ungu : Tidak Ungu & 1 (PrPrCCRRYY) & $\operatorname{PrPrCCRRYY}$ \\
\hline & $=1: 0$ & $3(\operatorname{PrPrCCRRYy)}$ & PrPrCCRRY-dan PrPrCCRRyy \\
\hline & & 17 (PrPrCCRRyy) & PrPrCCRRyy \\
\hline \multirow[t]{3}{*}{2.} & Ungu : Merah & 2 (PrprCCRRYY) & Pr-CCRRYY \\
\hline & $=3: 1$ & 4 (PrprCCRRYy) & PrPrCCRRY-dan PrPrCCRRyy \\
\hline & & 18 (PrprCCRRyy) & Pr-CCRRyy \\
\hline \multirow[t]{2}{*}{3.} & Ungu : Kuning & $5(\operatorname{PrPrCcRRYY})$ & $\operatorname{PrPrC}-R R Y Y$ \\
\hline & $=3: 1$ & $13(\operatorname{PrPrCCRrYY})$ & $\operatorname{PrPrCCR}-Y Y$ \\
\hline \multirow[t]{2}{*}{4.} & Ungu : Putih & 19 (PrPrCcRRyy) & PrPrC-RRyy \\
\hline & $=3: 1$ & 21 (PrPrCCRryy) & PrPrCCR-yy \\
\hline 5. & $\begin{array}{l}\text { Ungu : Kuning } \\
=9: 7\end{array}$ & $9(\operatorname{PrPrCcRrYY})$ & PrPrC-R-YY \\
\hline 6. & $\begin{array}{l}\text { Ungu : Putih } \\
=9: 7\end{array}$ & 23 (PrPrCcRryy) & PrPrC-R-yy \\
\hline 7. & $\begin{array}{l}\text { Ungu : Merah : Kuning } \\
=9: 3: 4\end{array}$ & $\begin{array}{l}6 \text { (PrprCcRRYY) } \\
14 \text { (PrprCCRrYY) }\end{array}$ & $\begin{array}{l}\text { Pr-C-RRYY } \\
\text { Pr-CCR-YY }\end{array}$ \\
\hline 8. & $\begin{array}{l}\text { Ungu : Merah : Putih } \\
=9: 3: 4\end{array}$ & $\begin{array}{l}20 \text { (PrprCcRRyy) } \\
22 \text { (PrprCCRryy) }\end{array}$ & $\begin{array}{l}\text { Pr-C-RRyy } \\
\text { Pr-CCR-yy }\end{array}$ \\
\hline 9. & $\begin{array}{l}\text { Ungu : Kuning : Putih } \\
=12: 3: 1\end{array}$ & $\begin{array}{l}7(\operatorname{PrPrCcRRYy}) \\
15(\operatorname{PrPrCCRYY})\end{array}$ & $\begin{array}{c}\text { PrPrC-RRY-dan } \\
\text { PrPrC-RRyy, PrPrCCR-Y-dan PrPrCCR-yy }\end{array}$ \\
\hline 10. & $\begin{array}{l}\text { Ungu : Merah : Kuning } \\
=27: 9: 28\end{array}$ & 10 (PrprCcRrYY) & $P r-C-R-Y Y$ \\
\hline 11. & $\begin{array}{l}\text { Ungu : Merah : Putih } \\
=27: 9: 28\end{array}$ & 24 (PrprCcRryy) & Pr-C-R-yy \\
\hline 12. & $\begin{array}{l}\text { Ungu : Kuning : Putih } \\
=36: 21: 7\end{array}$ & $11(\operatorname{PrPrCcRrYy})$ & $\begin{array}{l}\text { PrPrC-R-Y-dan } \\
\quad \text { PrPrC-R-yy }\end{array}$ \\
\hline 13. & $\begin{array}{l}\text { Ungu:Merah:Kuning:Putih } \\
=27: 9: 21: 7\end{array}$ & 12 (PrprCcRrYy) & Pr-C-R-Y-dan Pr-C-R-yy \\
\hline 14. & $\begin{array}{l}\text { Ungu:Merah:Kuning:Putih } \\
=9: 3: 3: 1\end{array}$ & $\begin{array}{l}8 \text { (PrprCcRRYy) } \\
16 \text { (PrprCCRrYy) }\end{array}$ & Pr-C-RRY-dan Pr-C-Rryy \\
\hline
\end{tabular}

Sumber : Data Hasil Olahan (2011)

\section{Tanaman $\mathrm{U}_{5}$}

Penyerbukan sendiri ke-1 (selfing ke-1 atau $\mathrm{S}_{1}$ ) pada tanaman $\mathrm{U}_{5}$ menghasilkan bulir $\mathrm{S}_{1}$ sebanyak 14:11 (ungu:kuning) yang sesuai dengan nisbah harapan 3:1 (ungu:kuning). Dengan demikian, dapat diprediksi bahwa genotipe tanaman $\mathrm{U}_{5}$ adalah PrPrCcRRYY atau PrPrCCRrYY. Penyerbukan sendiri ke-2 (selfing ke-2 atau $S_{2}$ ) pada tanaman $S_{1} U_{5}$ menghasilkan bulir $S_{2}$ yang sesuai de- ngan nisbah harapan 12:3:1 (ungu:kuning:putih) sehingga dapat diprediksi bahwa genotipe tanaman $\mathrm{S}_{1} \mathrm{U}_{5}$ adalah PrPrCcRRYy atau PrPrCCRrYy. Gen $Y y$ yang terdapat pada genotipe tanaman $S_{1} U_{5}$ memperlihatkan adanya penyimpangan pewarisan gen $Y Y$ dari tanaman $U_{5}$ kepada keturunannya yaitu $\mathrm{S}_{1} \mathrm{U}_{5}$. Penyimpangan tersebut dapat terjadi akibat pengaruh berbagai faktor yang secara genetik mempengaruhi genotipe warna bulir hasil selfing. 


\section{Tanaman $\mathrm{U}_{6}$}

Penyerbukan sendiri ke-1 $\left(S_{1}\right)$ pada tanaman $\mathrm{U}_{6}$ menghasilkan bulir $\mathrm{S}_{1}$ sebanyak 69:1 (ungu:kuning) yang tidak sesuai dengan nisbah harapan 3:1 atau 9:7 (ungu:kuning) sehingga genotipe tanaman $\mathrm{U}_{6}$ tidak dapat diprediksi. Bulir ungu hasil $S_{1}$ tanaman $U_{6}$ tersebut tetap digunakan sebagai benih untuk ditumbuhkan menjadi tanaman $\mathrm{S}_{1} \mathrm{U}_{6}$. Selfing ke-2 $\left(\mathrm{S}_{2}\right)$ tanaman $\mathrm{S}_{1} \mathrm{U}_{6}$ menghasilkan bulir $S_{2}$ yang sesuai dengan nisbah 36:21:7 (ungu:kuning:putih) dan 9:7 (ungu:putih) sehingga prediksi genotipe berdasarkan masing-masing nisbah harapan yaitu PrPrCcRrYy dan PrPrCcRryy.

Berdasarkan hasil penelitian, didapati beberapa penyimpangan pola pewarisan warna bulir ungu jagung yang ditandai dengan perbedaan genotipe tanaman $S_{1} U_{5}$, yaitu $\operatorname{PrPrCcRRYy}$ atau PrPrCCRrYy sedangkan genotipe tetuanya $\left(\mathrm{U}_{5}\right)$ adalah PrPrCcRRYY atau PrPrCCRrYY dan genotipe hasil selfing tanaman $\mathrm{U}_{5}$ adalah PrPrCCRRYY, PrPrCcRRYY, dan PrPrCCRrYY. Perbedaan genotipe tersebut terlihat dari genotipe $Y y$ pada genotipe tanaman $S_{1} U_{5}$ yang berbeda dari genotipe tetua $\left(U_{5}\right)$ yang bergenotipe $Y Y$.

Perbedaan yang terjadi pada komposisi genetik tanaman tetua pada populasi selfing dan bulir ungu hasil selfing dapat dijelaskan oleh pengaruh berbagai faktor yang secara genetik menyebabkan penyimpangan ekspresi genetik warna bulir. Penyimpangan pada karakter warna bulir tersebut dapat dipengaruhi oleh adanya gen pemodifikasi atau pengubah (modifying gene) yang ekspresinya dipengaruhi lingkungan. Gen pemodifikasi adalah gen yang mengubah ekspresi gen lain. Gen pemodifikasi dapat berperan sebagai penghambat (inhibitor), pendukung (enhancer), atau penekan (suppressor). Gen utama (gen mayor) mengatur penampilan fenotipe dari suatu karakter tetapi dapat berubah karena pengaruh beberapa atau banyak gen minor (Crowder, 2006). Suatu organisme mungkin memiliki genotipe tertentu tetapi tidak dapat mengekspresikan fenotipe yang diharapkan karena adanya modifying gene, gen epistasis atau pengaruh lingkungan yang berupa faktor-faktor dalam sel (intraseluler) dan faktorfaktor luar sel (ekstraseluler).

Penyimpangan pola pewarisan pada warna bulir jagung dapat pula disebabkan oleh sejumlah fragmen DNA yang dapat berpindah dan dikenal sebagai transposon. Transposon adalah unsur genetik kecil yang berisi seluruh gen yang memiliki kemampuan untuk mengalami transposisi atau gerakan ke lokus yang baru dalam genom. Transposon memiliki kemampuan untuk berpindah ke dalam genom secara acak sehingga mengganggu kemampuan ekspresi gen di dalamnya. Kehadiran transposon pada lokus gen yang mengendalikan ekspresi warna bulir jagung memungkinkan terjadinya penyimpangan dalam pewarisan gen warna bulir. McClintock menemukan adanya mekanisme mobilisasi gen dalam genom sehingga pola pewarisan suatu gen tidak mengikuti Hukum Pewarisan Mendel (Tornqvist, 2006).

Faktor lainnya yang secara genetik mempengaruhi pola pewarisan warna bulir ungu pada jagung adalah gen-gen lain yang berpengaruh terhadap pembentukan warna bulir jagung namun tidak diikutkan dalam model empat lokus ini. Gengen tersebut dapat berupa gen struktural yang berperan dalam pembentukan warna aleuron adalah gen $A 1, A 2$ dan $B z$ atau gen regulator $C$ dan $R$ yang memiliki beberapa alel misalnya alel $B$ dan $P I$ pada lokus $C$ dan alel $P, S, L C, n j$ dan $g$ pada lokus $R$ (Coe et. al., 1977). 
Tabel 3. Prediksi Nisbah Harapan Warna Bulir $\mathrm{S}_{1}$ dan $\mathrm{S}_{2}$ serta Genotipe Tanaman Tetua

(Table 3. Prediction Expected Ratio of $S_{1}$ and $S_{2}$ Kernel Colors and the Parent Genotypes)

\begin{tabular}{|c|c|c|c|c|c|c|c|c|c|c|c|c|c|}
\hline \multirow{3}{*}{$\begin{array}{l}\text { Tan. } \\
\text { Tetua }\end{array}$} & \multirow{2}{*}{\multicolumn{3}{|c|}{$\begin{array}{l}\text { Nisbah Pengamatan } \\
\text { Bulir Hasil S1 }\end{array}$}} & \multirow{3}{*}{$\begin{array}{l}\text { Nisbah } \\
\text { Harapan }\end{array}$} & \multirow{3}{*}{$\begin{array}{l}\text { Prediksi Genotipe } \\
\text { Tanaman Tetua }\end{array}$} & \multirow{3}{*}{$\begin{array}{l}\text { Genotipe bulir ungu } \\
\text { hasil S1 }\end{array}$} & \multirow{3}{*}{$\begin{array}{c}\text { Tanaman } \\
\text { S1 }\end{array}$} & \multicolumn{5}{|c|}{ Nisbah Pengamatan Bulir } & \multirow{3}{*}{ Prediksi Genotipe Tanaman S1 } \\
\hline & & & & & & & & \multirow[t]{2}{*}{ No. } & \multicolumn{3}{|c|}{ Hasil S2 } & \multirow[t]{2}{*}{ Nisbah Harapan } & \\
\hline & $u$ & $\mathrm{~K}$ & $P$ & & & & & & $u$ & $\mathrm{~K}$ & $P$ & & \\
\hline \multirow[t]{8}{*}{ U1 } & 93 & 72 & 31 & Terima & PrPrCcRryy & PrPrCCRRYY, & S1U1 & 1. & 137 & 115 & 30 & Terima 36:21:7 & PrPrCcRrYy \\
\hline & & & & $36: 21: 7$ & & PrPrCCRRYY, & & 2. & 32 & 14 & 4 & Terima 12:3:1 & PrPrCCRRYy atau PrPrCCRrYy \\
\hline & & & & & & PrPrCCRRYY, & & 3. & 142 & 90 & 21 & Terima 36:21:7 & PrPrCcRrYy \\
\hline & & & & & & PrPrCcRRYy, & & 4. & 108 & 54 & 11 & Terima 36:21:7 & PrPrCcRrYy \\
\hline & & & & & & PrPrCCRrYY, & & 5. & 10 & 3 & 2 & Terima 36:21:7 & PrPrCcRrYy \\
\hline & & & & & & PrPrCCRrYy, & & 6. & 24 & 17 & 6 & Terima 36:21:7 & PrPrCckrYy \\
\hline & & & & & & PrPrCCRryy, & & & & & & & \\
\hline & & & & & & PrPrCcRiry & & & & & & & \\
\hline \multirow[t]{4}{*}{ U2 } & 74 & 0 & 76 & Terima & PrPrCcRryy & PrPrCCRRyy, & S1U2 & 1. & 53 & 0 & 8 & Terima 3:1 & PrPrCcRRyy atau PrPrCCRryy \\
\hline & & & & $9: 7$ & & PrPrCcRRyy, & & 2. & 10 & 0 & 5 & Terima 9:7 & PrPrCcRryy \\
\hline & & & & & & PrPrCcRryy, & & & & & & & \\
\hline & & & & & & PrPrCCRryy & & & & & & & \\
\hline \multirow[t]{4}{*}{ U3 } & 12 & 13 & 0 & Terima & PrPrCCRrYY & PrPrCCRRYY, & S1U3 & 1. & 35 & 22 & 0 & Terima 9:7 & PrPrCcRrYY \\
\hline & & & & $9: 7$ & & PrPrCcRRYY, & & & & & & & \\
\hline & & & & & & PrPrCCRrYY, & & & & & & & \\
\hline & & & & & & PrPrCCRrYY & & & & & & & \\
\hline \multirow[t]{2}{*}{ U4 } & 51 & 1 & 8 & Tolak & Tidak dapat & Tidak dapat & S1U4 & 1. & 119 & 41 & 0 & Terima 3:1 & PrPrCcRRYY atau PrPrCCRrYY \\
\hline & & & & 12:3:1 & diprediksi & diprediksi & & 2. & 259 & 4 & 0 & Tolak 3:1 \& 9:7 & Tidak dapat diprediksi \\
\hline \multirow[t]{4}{*}{ U5 } & 14 & 11 & 0 & Terima & PrPrCcRRYY & PrPrCCRRYY, & S1U5 & 1. & 43 & 9 & 8 & Terima 12:3:1 & PrPrCCRRYy atau PrPrCCRrYy \\
\hline & & & & 3:1 & Atau & PrPrCCRRYY & & & & & & & \\
\hline & & & & & PrPrCCRrYY & PrPrCCRRYY, & & & & & & & \\
\hline & & & & & & PrPrCCRrYY & & & & & & & \\
\hline \multirow[t]{6}{*}{ U6 } & 69 & 1 & 0 & Tolak 3:1 & Tidak dapat & Tidak dapat & S1U6 & 1. & 151 & 107 & 4 & Tolak 36:21:7 \& 12:3:1 & Tidak dapat diprediksi \\
\hline & & & & $\& 9: 7$ & diprediksi & diprediksi & & 2. & 96 & 43 & 16 & Terima 36:21:7 & PrPrCcRrYy \\
\hline & & & & & & & & 3. & 233 & 140 & 37 & Terima 36:21:7 & PrPrCcRrYy \\
\hline & & & & & & & & 4. & 129 & 84 & 0 & Terima 9:7 & PrPrCcRrYY \\
\hline & & & & & & & & 5. & 13 & 4 & 8 & Tolak 36:21:7 \& 12:3:1 & Tidak dapat diprediksi \\
\hline & & & & & & & & 6. & 122 & 57 & 22 & Terima 36:21:7 & PrPrCcRrYy \\
\hline
\end{tabular}

Ket : U=Ungu, K=Kuning, $\mathrm{P}=$ Putih, $P r=$-Gen pengendali warna ungu pada bulir, $Y$ - atau $y y=G e n$ pengendali warna kuning atau putih pada bulir $C$ - dan $R-=$ Gen pengendali adanya warna bulir. 


\section{KESIMPULAN}

Genotipe tetua jagung berbulir ungu dapat diprediksi berdasarkan kesesuaian nisbah harapan pada bulir $S_{1}$ dan $S_{2}$. Prediksi genotipe tetua pada populasi dasar selfing adalah PrPrCcRrYy, PrPrCcRryy, PrPrCcRrYY, PrPrCcRRYY dan PrPrCCRrYY.

\section{SARAN}

Perlu dilakukan penelitian lanjutan mengenai pewarisan sifat warna bulir ungu pada jagung dengan menggunakan model lebih dari empat lokus dan material genetik berupa bulir jagung yang homozigot.

\section{DAFTAR PUSTAKA}

Coe, Jr., E.H. and M.G. Neuffer. 1977. The Genetics of Corn. In G.F. Sprague (ed). Corn and Corn Improvement. American Society of Agronomy. Wisconsin.

Crowder, L.V. 2006. Genetika Tumbuhan. Terjemahan. Gadjah Mada University Press. Yogyakarta.

Donner, H.K., T.P. Robbins, and R.A. Jorgensen. 1991. Genetic and Developmental Control of Anthocyanin Biosynthesis. Annual Review of Genetics. (25):173-199.
East, E.M. 1912. Inheritance Color in The Aleurone Cells of Maize. The American Naturalist. (46):363-365.

Elbehri, A. 2005. Biopharming and the Food System: Examining the Potential Benefits and Risks. AgBioForum. (8):18-25.

Ford, R.H. 2000. Inheritance of Kernel Color in Corn: Explanation and Investigation. The American Biology Teacher. University of California Press. (62):181-188.

Kempton, J.H. 1919. Inheritance of Spotted Aleuron Color in Hybrid of Chinese Maize. U.S Bureau of Plant Industry. Washington D.C.

Klug, W.S, and M.R. Cummings. 1997. Concepts of Genetics $5^{\text {th }}$ Edition. Prentice-Hall, Inc. New Jersey.

Purwanto, S.T. 2008. Perkembangan Produksi dan Kebijakan dalam Peningkatan Produksi Jagung. Direktorat Budidaya Serealia, Direktorat Jenderal Tanaman Pangan.

Sharma, M., M. Cortes-Cruz., K. R. Ahern, M. McMullen, T. P. Brutnell, and S. Chopra. 2011. Identification of the Pr1 Gene Product Completes the Anthocyanin Biosynthesis Pathway of Maize. Genetics Society of America. 69-79.

Tornqvist, C.E. 2006. Plant Genetics. Chelsea House Publisher. New York. 
